\title{
Identification of Phytophthora spp. isolated from plants and soil samples on strawberry plantations in Poland
}

\author{
Beata Meszka ${ }^{1} \cdot$ Monika Michalecka $^{1}$
}

Received: 21 April 2015/ Accepted: 5 November 2015/Published online: 24 February 2016

(C) Deutsche Phythomedizinische Gesellschaft 2016. This article is published with open access at Springerlink.com

\begin{abstract}
Crown and leather rot of strawberry caused by Phytophthora spp. are major soil diseases of cultivated strawberry (Fragaria $\times$ ananassa) in Poland. In this study, in total 45 isolates of Phytophthora spp. from plants of cultivars Elsanta, Honeoye, Florence, Camarosa, Roxana, Onebor, Alba, Elegance, Albion, Senga Sengana and Malwina originating from crowns (20 isolates) and fruits (25 isolates) as well as 25 soil samples from the same fruiting strawberry plantations located in central, northeastern, and south-eastern regions of Poland were identified. Among them, 44 isolates from plant organs and eight from soil samples were identified as Phytophthora cactorum and from one plant and one soil sample as $P$. citricola; of those remaining from the soil, one was identified as $P$. citrophthora and one as $P$. cryptogea. Identifications were based on morphological characteristics and DNA analyses. Species-specific polymerase chain reaction confirmed the presence of Phytophthora spp. in all positive examined plant and soil samples and confirmed that $P$. cactorum is predominantly responsible for crown and leather rot diseases of strawberry in monitored regions of Poland. Pathogenicity tests showed that all isolates of Phytophthora spp. originating from soil derived from strawberry plantations were pathogenic both to strawberry and to raspberry.
\end{abstract}

Keywords Crown rot $\cdot$ Fragaria $\times$ ananassa . Identification - Leather rot · Molecular detection . Phytophthora spp.

Beata Meszka

beata.meszka@inhort.pl

1 Research Institute of Horticulture, Konstytucji 3 Maja 1/3, 96-100 Skierniewice, Poland

\section{Introduction}

Phytophthora is a genus of plant pathogenic filamentous oomycetes (phylum: Oomycota), which, morphologically, are very similar to the filamentous fungi from the kingdom Fungi [2]. Phytophthora cactorum was first identified on cacti in 1870 by Lebert and Cohn [12], and it currently infects an extremely large number of plant hosts. It can limit production of many economically important crops, such as apple, pear, rhododendron, azalea, and strawberry [13]. Phytophthora cactorum can cause root, collar, and crown rots as well as foliar and fruit damage; thus, it is among the most serious soil-borne pathogens affecting crops worldwide [20]. In Poland, P. cactorum causes serious strawberry yield losses due to plant stunting and collapse, especially on susceptible cultivars, such as Elsanta, Honeoye, Elegance, Onebor. Stunting of whole plants or wilting of young leaves are the first symptoms and may appear at any time during the season. The pathogen infects the underground parts by motile zoospores and then colonises strawberry crown. As a result, a typical uniform brown discoloration is visible after the crown cross section, which may appear at the base or in the middle of the crown [4]. Severe infection of the crown leads to dysfunction of the vascular system and to dieback of roots. Leaf margins begin to turn brown and entire leaves wilt, often quickly, and, finally, the whole plant dies. Symptoms of strawberry crown rot can be similar to those elicited by Colletotrichum acutatum and Verticillium dahliae, which are commonly encountered on strawberry plantations in Poland. Therefore, identification of the causal agents of soil-borne diseases on strawberry plantations is an important issue in preventive and pest control management.

The purpose of this study was to investigate (1) which species of Phytophthora are causing necrosis on strawberry 
fruits and plants; (2) which species are occurring in soil samples and are involved in the decline of strawberry plants in central, north-eastern, and south-eastern regions of Poland; and (3) the pathogenicity of Phytophthora spp. present in soil for strawberry and raspberry plants.

\section{Materials and methods}

\section{Sampling and isolation procedure}

In 2013-2014, plants with visible disease symptoms of crown rot and/or leather rot were sampled from 25 strawberry fruiting plantations in the central, north-eastern, and south-eastern regions of Poland (Table 1).

Small fragments of infected plant organs (fruit, root crown) were surface-disinfected by dipping in $0.5 \%(\mathrm{w} / \mathrm{v})$ sodium hypochlorite for 2-5 min and rinsed with sterile water before they were placed onto potato dextrose agar (PDA, Sigma-Aldrich Sp.z.o.o, Poznań, Poland) containing streptomycin, in 90-mm Petri dishes. For each plant organ, four Petri dishes were used, each with 10 tissue pieces. Subsequently, plates were incubated at $25{ }^{\circ} \mathrm{C}$ until the mycelial growth was observed. After 3-5 days of growth on PDA at $22{ }^{\circ} \mathrm{C}$, isolates were identified by morphological and cultural characteristics [7, 12]. Finally, 45 isolates of Phytophthora spp. from fruits and/or crowns of strawberry cultivars Elsanta, Honeoye, Florence, Camarosa, Roxana, Onebor, Alba, Elegance, Albion, Senga Sengana and Malwina were obtained. The severity of leather rot on strawberry fruits was evaluated on three selected plantations by counting all healthy and infected fruits on 26 plants in each of four randomly chosen plots during harvest. The results were analysed statistically by the variance analysis method on per cent data transformed according to the Bliss function. The differences between means were estimated by the Newman-Keuls test at the $5 \%$ level of significance.

Isolations from soil samples were made from the same 25 fruiting strawberry plantations (Table 1). Bulked soil samples (about $1.0 \mathrm{~kg}$ ) were collected from 10 randomly chosen positions of each plantation, at a depth of

Table 1 Strawberry plantations in central, north-eastern, and south-eastern Poland included in this study

\begin{tabular}{|c|c|c|c|c|c|}
\hline Location of strawberry plantation & Cultivar & Area (ha) & Soil texture & Soil pH & Plant material for study \\
\hline Bobrowiec $[\mathrm{C}]$ & Honeoye & 0.7 & Sandy and loamy clay & 6.0 & Crown, fruit \\
\hline Chynów [C] & Onebor & 0.5 & Sandy clay above clay & 6.2 & Fruit \\
\hline Konin $[\mathrm{C}]$ & Honeoye & 0.3 & Podzol and fawn & 6.2 & Fruit \\
\hline Godzianów [C] & Honeoye & 0.5 & Light soil sand & 6.2 & Crown, fruit \\
\hline Jankowice $[\mathrm{C}]$ & Malwina & 0.5 & Sandy clay & 5.0 & Crown, fruit \\
\hline Skierniewice $1[\mathrm{C}]$ & Elegance & 3.0 & Sandy clay & 5.5 & Crown, fruit \\
\hline Skierniewice $2[\mathrm{C}]$ & Elsanta & 2.0 & Sandy clay & 6.4 & Fruit \\
\hline Wilcze Średnie $[\mathrm{C}]$ & Florence & 2.0 & Sandy clay & 6.0 & Crown, fruit \\
\hline Teodozjów [C] & Roxana & 0.3 & Clayey soil & 5.5 & Fruit \\
\hline Radziejowice $[\mathrm{C}]$ & Elegance & 0.7 & Sandy clay & 6.2 & Crown, fruit \\
\hline Karsznice $[\mathrm{C}]$ & Honeoye & 2.0 & Clayey soil & 6.5 & Crown, fruit \\
\hline Zdziarka [C] & Alba & 0.5 & Sandy clay & 5.0 & Crown, fruit \\
\hline Wilga [C] & Malwina & 0.7 & Sandy clay & 6.0 & Crown, fruit \\
\hline Wilków [E] & Onebor & 0.5 & Sandy clay & 5.5 & Crown, fruit \\
\hline Szydłówka [E] & Albion & 3.2 & Light soil sand & 6.0 & Crown, fruit \\
\hline Tuszewo $[\mathrm{N}-\mathrm{E}]$ & Camarosa & 1.0 & Sandy clay & 5.0 & Crown, fruit \\
\hline Zarzecze $[\mathrm{E}]$ & Elegance & 0.5 & Clayey soil & 6.0 & Crown, fruit \\
\hline Huszlew [E] & Elsanta & 0.3 & Sandy clay & 5.8 & Crown, fruit \\
\hline Serniki [E] & Elsanta & 0.4 & Light soil & 6.0 & Crown, fruit \\
\hline Zosinek [E] & Senga Sengana & 0.2 & Sand & 6.0 & Crown, fruit \\
\hline Dzierzkowice-Wola [E] & Honeoye & 1.0 & Sandy clay & 6.2 & Crown, fruit \\
\hline Łubianki [E] & Camarosa & 1.5 & Clayey soil & 6.0 & Crown, fruit \\
\hline Tuszewo $[\mathrm{N}-\mathrm{E}]$ & Camarosa & 1.0 & Sandy clay & 5.0 & Crown, fruit \\
\hline Orneta [N-E] & Onebor & 1.0 & Sandy clay & 5.5 & Fruit \\
\hline Mrągowo [N-E] & Honeoye & 1.0 & Loam & 5.5 & Crown, fruit \\
\hline Bogumiłowice [S-E] & Honeoye & 0.7 & Sandy clay & 6.0 & Crown, fruit \\
\hline
\end{tabular}

C, E, N, S-region in Poland: $E$ eastern, $C$ central, $N$ northern, and $S$ southern 
10-15 cm, and stored at room temperature. For Phytophthora spp. isolation, the baiting test according to Themann et al. [23] was conducted. Trays were filled with tap water to about $1 \mathrm{~cm}$ above soil level, and leaves of Rhododendron cultivar Nova Zembla (8-10 leaves per tray) were floated on the surface. After 5-7 days of incubation at 21-23 ${ }^{\circ} \mathrm{C}$, Rhododendron leaves were harvested, washed under tap and deionised water, and dabbed dry. Then, segments of $5 \mathrm{~mm}$ diameter were cut from individual necrotic spots and placed onto PDA in 90-mm Petri dishes, 25 pieces per dish, each in five replicates. Within the next 2 days, hyphae growing from the plated segments were assessed under an optical microscope for the presence of sporangia. Small fragments from the edge of growing microorganisms were transferred onto new PDA plates in order to obtain pure cultures.

\section{Classification of isolates into the Phytophthora genus}

After 5-7 days of growth on PDA at $22{ }^{\circ} \mathrm{C}$, isolates were identified by morphological and cultural characteristics [12, 18]. The isolates were cultured on PDA in darkness at $25^{\circ} \mathrm{C}$ for 14 days. Characteristic morphology of Phytophthora spp. mycelial growth and the presence of sporangia and/or oogonia were observed. Additionally, sporangia were produced by flooding round mycelial discs of $6 \times 6 \mathrm{~mm}$ in diameter taken from growing margins of 3- to 5-day-old colonies on PDA, $1 \mathrm{~mm}$ over their surface, with non-sterile soil extract [18] in 90-mm Petri dishes and incubating them in the dark at $18-22{ }^{\circ} \mathrm{C}$. Soil extract was replaced with a fresh one every 24 hours. After three days mycelial fragments were taken from the growing edge of submerged PDA plugs and transferred onto microscopic slides. Zoosporangia and oogonia were observed at $400 \times$ magnification under a light microscope Delta Optical Evolution 300 LED (Delta Optical, Mińsk Mazowiecki, Poland).

\section{DNA extraction from Phytophthora spp. cultures}

From 2- to 5-day-old Phytophthora spp. cultures of 45 isolates, about 50-100 mg of fresh mycelia were cut out, and total DNA was extracted following the Aljanabi and Martinez [1] protocol for DNA extraction. DNA was suspended in $50 \mu \mathrm{l}$ of double-deionised water and kept at $-20{ }^{\circ} \mathrm{C}$ for further analyses.

\section{PCR with species-specific primers and sequence analysis}

The obtained DNA was tested in PCR with the six primer sets (Table 2) specific for the following Phytophthora species: $P$. citricola, $P$. citrophthora, $P$. cinnamomi, $P$. cryptogea, $P$. cactorum, and $P$. fragariae. Conditions for PCR were as follows: an initial denaturation step of $3 \mathrm{~min}$ at $94{ }^{\circ} \mathrm{C}$, followed by 30 cycles of $30 \mathrm{~s}$ of denaturation at $94{ }^{\circ} \mathrm{C}$; $30 \mathrm{~s}$ of annealing at $60{ }^{\circ} \mathrm{C}$ for $P$. fragariae-specific primers or at $66{ }^{\circ} \mathrm{C}$ for the other primers; and $60 \mathrm{~s}$ of polymerisation at $72{ }^{\circ} \mathrm{C}$. The final elongation step was $5 \mathrm{~min}$ at $72^{\circ} \mathrm{C}$. Each PCR mixture consisted of the following: $10-30 \mathrm{ng}$ of total DNA template, $500 \mathrm{nM}$ of reverse and $500 \mathrm{nM}$ of forward primers of one speciesspecific set, $0.2 \mathrm{mM}$ of each dNTP, 0.45 unit of DreamTaq Green DNA Polymerase (Thermo Scientific, Vilnius, Lithuania), $1 \times$ optimised DreamTaq Green Buffer, and double-distilled water in a total volume of $15 \mu \mathrm{l}$. All reactions were performed in a Biometra T3000 Thermocycler (Biometra, Göttingen, Germany). Then, PCR
Table 2 List of primers used in this study and their nucleotide sequences

\begin{tabular}{|c|c|c|c|}
\hline Primer name & Primer sequence $\left(5^{\prime} \rightarrow 3^{\prime}\right)$ & Target organism & References \\
\hline \multicolumn{4}{|c|}{ Phytophthora spp.-specific primers } \\
\hline Primer \#1 & GTCGACGTCCTGCTTGGCACTCTG & P. citrophthora & Ersek et al. [11] \\
\hline Primer \#2 & CGGTGCTCCGCGACTGTTGTCCAC & P. citrophthora & Ersek et al. [11] \\
\hline CITR1 & TCTTGCTTTTTTTGCGAGCC & P. citricola & Schubert et al. [21] \\
\hline CITR2 & CGCACCGAGGTGCACACAAA & P. citricola & Schubert et al. [21] \\
\hline ADF1 & TACTGTGGGGACGAAAGTCCT & P. cactorum & Boersma et al. [5] \\
\hline ADR1 & CCGATTCAAAAGCCAAGCAACT & P. cactorum & Boersma et al. [5] \\
\hline DG9 & AACTGAGCTAGTAGCCTCTC & P. cinnamomi & Boersma et al. [5] \\
\hline DC5 & CGCCGACTGGCCACACAG & P. cinnamomi & Boersma et al. [5] \\
\hline CRYF2 & CGGTTTTCGGCTGGCTGGG & P. cryptogea & Boersma et al. [5] \\
\hline CRYR2 & CAGCTTGCGCCAGAACAGAC & P. cryptogea & Boersma et al. [5] \\
\hline DC1 & ACTTAGTTGGGGGCCTGTCT & P. fragariae & Bonnants et al. [6] \\
\hline DC5 & CGCCGACTGGCCACACAG & P. fragariae & Bonnants et al. [6] \\
\hline \multicolumn{4}{|c|}{ Primers for amplification of fungal and oomycetal rDNA region } \\
\hline ITS1 & TCCGTAGGTGAACCTGCGG & Fungi and oomycetes & White et al. [26] \\
\hline ITS4 & TCCTCCGCTTATTGATATGC & Fungi and oomycetes & White et al. [26] \\
\hline
\end{tabular}


products were separated during electrophoresis on $1.5 \%$ (w/v) gels, stained with ethidium bromide, and visualised using a transilluminator UV (Sigma T1202; SigmaAldrich, St. Louis, USA). The obtainment of the propersize PCR products was confirmed by comparison with the DNA of the reference strains, showing positive signals with the species-specific primers. For three selected isolates, GL1, BT1, and WG1 (identified as Phytophthora spp. in the PCR assay), and for those DNA samples derived from Phytophthora-like colonies growing in the baiting test for which no PCR product was obtained in species-specific PCRs, the DNA was amplified with ITS1 and ITS4 primers, specific for ITS (internal transcribed spacer) regions of filamentous fungi and oomycetes [26], and subjected to sequence analysis. The obtained DNA sequences were compared with the sequences available in the GenBank database using the Basic Local Alignment Search Tool (www.ncbi.nlm.nih.gov/BLAST/) and deposited in GenBank (National Center for Biotechnology Information), with accession numbers assigned to them.

\section{Pathogenicity of Phytophthora spp. from strawberry plantations to raspberry and strawberry plants}

Pathogenicity tests were conducted with isolates derived from soil samples from strawberry plantations: two isolates of $P$. cactorum (GL1, Serniki, and BT1, Tuszewo) and one of $P$. citricola (WG1, Serniki). In June 2014, leaf petioles of the strawberry cultivar Elsanta and stems of the raspberry cultivar Polka were taken and washed under tap water, dabbed dry, and transferred to trays onto moist, sterile blotting paper covered with a plastic net. Threemillimetre-diameter discs cut from the growing margins of 5-day-old PDA cultures of the three examined Phytophthora spp. isolates were placed on strawberry leaf petioles and stems of raspberry and covered with parafilm. Control plant material received plain PDA discs. Trays were covered with the foil and incubated at $24{ }^{\circ} \mathrm{C}$. For the experiment, each of 10 leaf petioles and canes per isolate-host combination conducted in four replicates was randomised. Length of necrosis was measured on the fifth (raspberry) and eighth days (strawberry) after inoculation. The experiment was repeated twice. In order to fulfil Koch's postulates, the causal agents of observed symptoms were reisolated on PDA plates, identified using molecular tests, and used for reinfection of plants.

\section{Statistical analyses}

Results from the different pathogenicity trials were analysed using analysis of variance (ANOVA) followed by the Tukey HSD test for multiple comparisons (STATISTICA 10; StatSoft Polska, Kraków, Poland).

\section{Results and discussion}

\section{Classification of Phytophthora spp. isolates on the basis of morphological traits}

On the basis of morphological trait estimation during Phytophthora spp. growth in pure cultures (colony characters, conidial and setal morphology, and production of sporangia and/or oogonia), 44 isolates derived from examined plant tissues were classified as $P$. cactorum and one as a $P$. citricola. Among cultures growing in baiting tests, typical Phytophthora-like morphology was observed for 10 soil samples. For fast detection of Phytophthora species in strawberry plants, culture-based isolation methods are widely used. On PDA media, P. cactorum usually forms a white, loosely matted colony. Sporangia are distinctively papillate and are usually borne terminally. Each sporangium may contain more than 50 zoospores [10]. According to Waterhouse [25], P. citricola can be readily differentiated from $P$. cactorum var. applanata on the basis of some morphological features. In culture, $P$. citricola tends to grow in a petaloid manner, while $P$. cactorum grows uniformly fluffy. Moreover, the apex of a sporangium of $P$. citricola is flat and wide with shallow thickening, while in $P$. cactorum prominent papillae with deep thickenings can be observed. Described differentiating features were also observed for these species in our study (Fig. 1a, b, e, f). Sporangia and oogonia produced by $P$. cactorum isolates on PDA media were observed after 10 days of cultivation, whereas $P$. citricola growing on PDA produced only oogonia; sporangia of the latter species were observed on the third day of cultivation in non-sterile soil extract. The oogonia of $P$. citricola were similar in size to those of $P$. cactorum (Fig. 1i, h). Our observations of growing cultures obtained in baiting tests were similar to those previously described for Phytophthora spp.; therefore, it was also possible to preliminarily classify the oomycetes as $P$. citricola and $P$. cactorum and, additionally, to $P$. citrophthora and P. cryptogea. Phytophthora citrophthora showed stellate, rosettal growth on PDA medium (Fig. 1c) and was able to produce sporangia in non-sterile soil extract (Fig. 1g), but oogonia were not observed on PDA medium, nor in soil extract. Colonies of P. cryptogea were fairly fluffy and cottony, with lobate margins and a slight floral pattern (Fig. 1d), but they did not produce sporangia nor oogonia on PDA or in soil extract. The lack of the production of oogonia by $P$. cryptogea and $P$. citrophthora is consistent with the previous observations $[12,19]$ that these species are heterothallic and require crossing with an opposite mating type to form oogonia and oospores. 


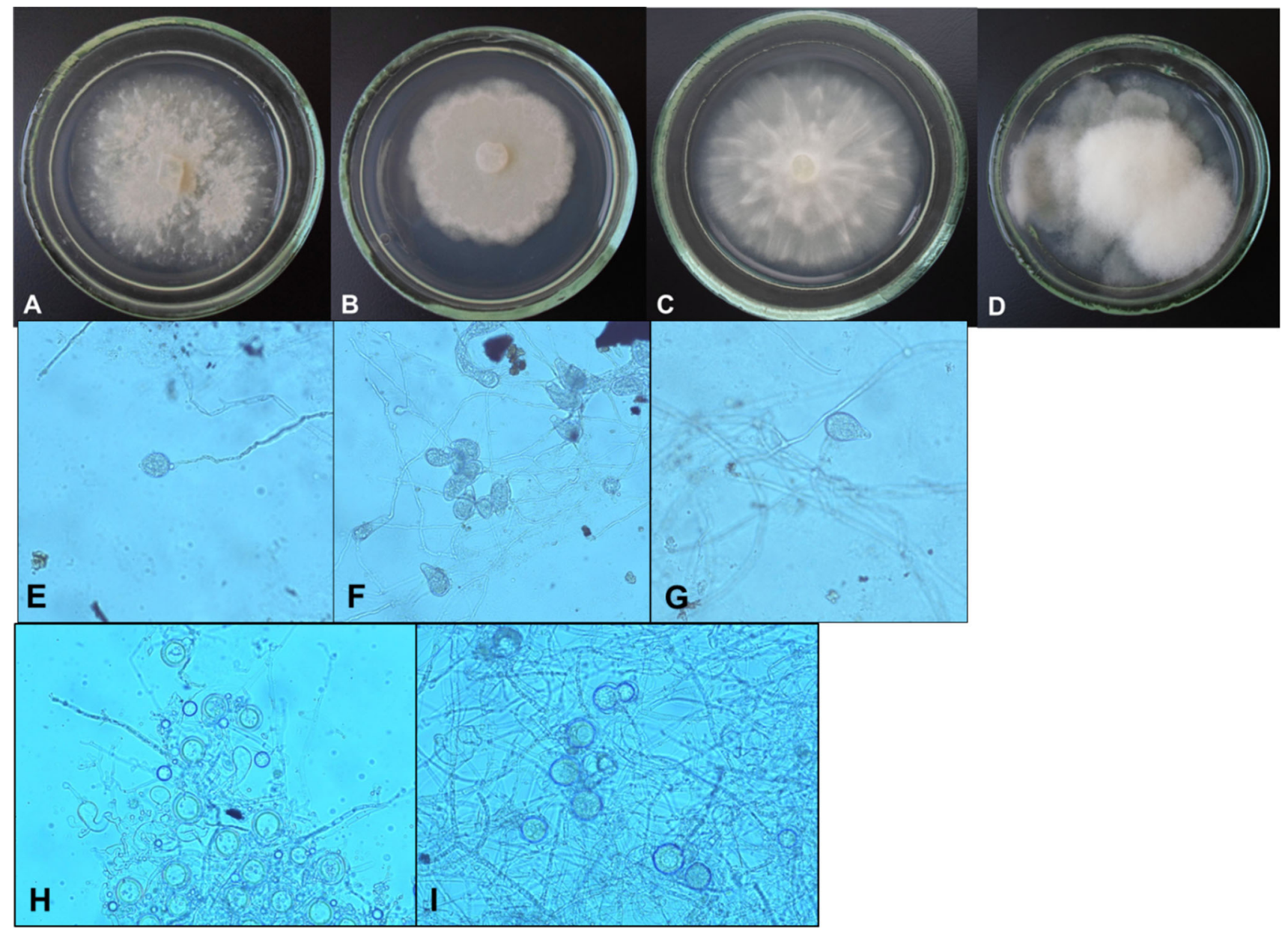

Fig. 1 Macroscopic and microscopic features of Phytophthora spp. growing in cultures on potato dextrose agar (PDA). The colonies photographed on the sixth day of incubation: a $P$. citricola (isolate WG1), b P. cactorum (isolate BT1), c P. citrophthora (strain RH04/ CTPH), and d P. cryptogea (isolate from Zarzecze). Morphology of

\section{Phytophthora spp. identification in PCR assays}

In PCRs with six Phytophthora species-specific primer sets, the presence of the proper-size products of reactions was observed on agarose gel. For 45 tested DNA samples obtained from Phytophthora spp. isolates from diseased plant tissues, positive signals for $P$. cactorum were observed (44 isolates) but only one for $P$. citricola (Table 3).

From 25 soil samples, only in $20 \%$ (nine soil samples) were Phytophthora spp. strains trapped and recognised in the baiting test. In the PCR assay, isolates from eight plantations were identified as $P$. cactorum, from one as $P$. cryptogea (Zarzecze), from one as $P$. citrophthora (Tuszewo), and from one as P. citricola (Serniki) (Table 3). This may suggest that Phytophthora spp. propagules are transferred between plantations mostly by strawberry stocks. It has been also reported that Phytophthora spp. can survive in infected host tissue $[14,22]$. zoosporangia of e $P$. cactorum (isolate BT1), f $P$. citricola (isolate WG1), and $\mathbf{g} P$. citrophthora (strain RH04/CTPH). Morphology of oogonia of $\mathbf{h} P$. cactorum (isolate BT1) and i $P$. citricola (isolate WG1). Magnification under light microscope $\times 400$

In the case of those Phytophthora spp. isolates for which sequencing of the ITS rDNA region and its comparison with reference sequences in GenBank were performed, the species classification was consistent with the results of the PCR assay. BLAST analysis of obtained DNA sequences of GL1 (GenBank Acc. No. KT361202) and BT1 (GenBank Acc. No. KT361201) showed $100 \%$ similarity with the corresponding region of reference of the P. cactorum strain (GenBank Acc. No. GU111587.1), while the sequence of the WG1 isolate (GenBank Acc. No. KT361200) was $100 \%$ similar to the sequence of $P$. citricola E strain (GenBank Acc. No. AF266788.1).

For other microorganisms whose colonies were obtained in the baiting test, the sequence analysis of the ITS rDNA region demonstrated the presence of fungi or oomycetes from the genera Pythium, Fusarium, Rhizopus, and Mortierella. Species identification based on morphological and physiological characters is a primary approach, although it is mostly laborious and time-consuming. Due to high intra- 
Table 3 Detection of Phytophthora spp. in plant and soil samples in the PCR assay

\begin{tabular}{|c|c|c|c|c|}
\hline Location of plantation & P. cactorum & P. citricola & P. citrophthora & P. cryptogea \\
\hline Bobrowiec & Crown, fruit & & & \\
\hline Bogumiłowice & Crown & Crown & & \\
\hline Chynów & Fruit & & & \\
\hline Dzierzkowice-Wola & Crown & & & \\
\hline Godzianów & Crown, fruit & & & \\
\hline Huszlew & Crown, fruit & & & \\
\hline Jankowice & Crown & & & \\
\hline Karsznice & Soil, fruit & & & \\
\hline Konin & Fruit & & & \\
\hline Łubianki & Crown & & & \\
\hline Mrągowo & Crown & & & \\
\hline Orneta & Fruit & & & \\
\hline Radziejowice & Crown & & & \\
\hline Serniki & Soil [GL1] & Soil [WG1] & & \\
\hline Skierniewice 1 & Soil, crown & & & \\
\hline Skierniewice 2 & Fruit & & & \\
\hline Szydłówka & Soil, crown & & & \\
\hline Teodozjów & Fruit & & & \\
\hline Tuszewo & Soil [BT1] & & Soil & \\
\hline Wilcze Średnie & Soil, fruit & & & \\
\hline Wilga & Crown & & & \\
\hline Wilków & Soil, crown & & & \\
\hline Zarzecze & Crown & & & Soil \\
\hline Zdziarka & Crown & & & \\
\hline Zosinek & Soil, crown & & & \\
\hline
\end{tabular}

species variability and small inter-species differences between Phytophthora species, additional confirmation is often required. Techniques based on the PCR method offer rapid, simple, and reliable identification of fungal and oomycetal species. Not only can species be identified in pure cultures, but it is also possible to detect pathogens directly in plant material and soil, which highly facilitates the possibility for specific monitoring of these pathogens. On the basis of some species-specific regions in the genome of Phytophthora, Ersek et al. [11] developed speciesspecific primers for $P$. parasitica and $P$. citrophthora detection. The variability in the DNA regions of ITS regions of rRNA of Phytophthora spp. has been also examined by Schubert et al. [21] and Boersma et al. [5]; thus, it became possible to discriminate species within the Phytophthora genus using species-specific primers designed by those authors. Because of recent changes in the $P$. citricola complex-the new species $P$. plurivora $\mathrm{sp}$. nov. was designated [18] — there was a need to additionally confirm the species affiliation of the WG1 $P$. citricola isolate by comparing its ITS1-5.8S-ITS2 rDNA region with the sequence of reference strains from this complex, available in GenBank database.

\section{Association of Phytophthora spp. presence with yield loss}

Excessive rainfall during the 2013 growing season was associated with heavy losses in strawberry crop due to fruit rot. Leather rot caused by $P$. cactorum accounted for up to $11 \%$ yield loss depending on cultivar (Fig. 2) within three examined plantations. Propagules of $P$. cactorum are readily dispersed from infected strawberry fruit by

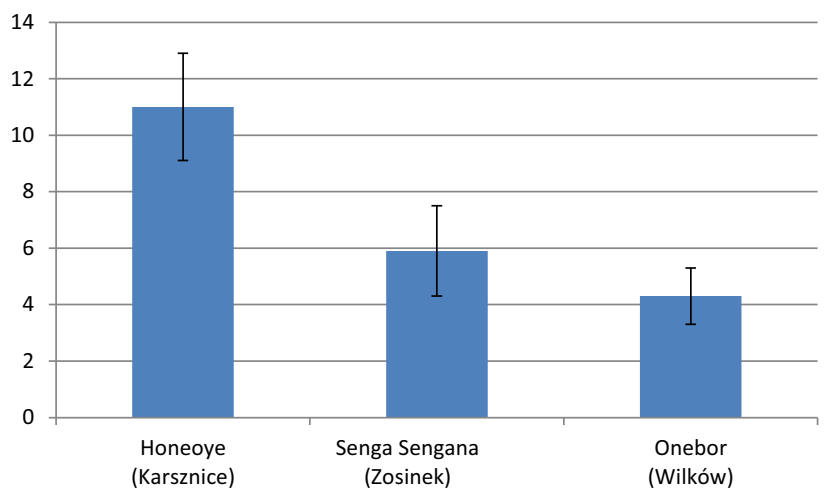

Fig. 2 Severity of leather rot of strawberry in the 2013 season 
Table 4 Length of necrosis produced on petioles of strawberry and raspberry canes after infection by Phytophthora spp.

\begin{tabular}{lllll}
\hline $\begin{array}{l}\text { Name of } \\
\text { isolate }\end{array}$ & Source & $\begin{array}{l}\text { Species of } \\
\text { Phytophthora }\end{array}$ & Average length of necrosis $(\mathrm{mm})$ & Strawberry leaf petioles \\
\cline { 4 - 5 } & & Raspberry cane & $0.0 \mathrm{a}$ \\
\hline Control & - & P. cactorum & $0.0 \mathrm{a}$ * & $42.7 \mathrm{~b}$ \\
GL1 & Soil & P. cactorum & $8.2 \mathrm{ab}$ & $32.0 \mathrm{~b}$ \\
BT1 & Soil & P. citricola & $19.7 \mathrm{~b}$ & $49.5 \mathrm{~b}$ \\
WG1 & Soil & & MS between groups $=119.06$ & MS between groups $=521.63$ \\
& & $d f=36$ & $d f=36$ \\
\hline
\end{tabular}

* The same letters indicate lack of statistically significant differences between values in columns, according to the Tukey test

splashing water [16]. Gerlach et al. [14] showed that zoospores of $P$. citrophthora were readily dispersed to potted Pieris japonica by water. Outbreaks of fruit rot on apple caused by $P$. syringae in the UK were related to the heavy rains, and inoculum was splashed with infested leaf debris on the orchard floor [24]. Phytophthora spp. spread mainly through the movement of infested soil, water, and infected plants or plant material; however, there are species that are transmitted aerially $[8,15]$. Especially substantial as a source of inoculum are those plants that are infected but do not show symptoms either because the disease has not yet progressed to the stage where symptoms are evident. Therefore, the major challenge in preventing the spread of Phytophthora is detection of the pathogen in asymptomatic tissue.

\section{Pathogenicity of Phytophthora spp. from soil samples to raspberry and strawberry}

The average length of necrosis on raspberry cane ranged from 8.0 to $19.7 \mathrm{~mm}$, while on strawberry leaf petioles it ranged from 32.0 to $49.5 \mathrm{~mm}$, depending on the isolate of Phytophthora spp. (Table 4). The longest necrosis was observed for isolate WG1 (P. citricola), and the smallest, for isolate BT (P. cactorum); however, this difference was not significant. All isolates of Phytophthora were successfully reisolated from symptomatic tissues and identified using molecular tests, fulfilling Koch's postulates.

This study shows that two $P$. cactorum and one $P$. citricola strains isolated from soil samples collected in the strawberry plantations where disease symptoms were observed were pathogenic both to strawberry plants and to raspberry plants, causing necrotic lesions on wounded leaf petioles and raspberry canes. The differentiation in $P$. cactorum isolates according to host preference was found in studies of Cooke et al. [9] and Hantula et al. [17]. Bielenin [3] reported that isolates of $P$. cactorum both from strawberry crowns and from fruit caused distinctly smaller necrosis symptoms on apple shoots than isolates from apple trees.
In conclusion, we have shown on the basis of morphology and DNA sequence analysis that the P. cactorum species is the most common causal agent of strawberry infections in Poland. Under favourable weather conditions for development and spread of the pathogen (high humidity and temperatures above $20^{\circ} \mathrm{C}$ ), it causes significant losses in yield of strawberries as well as decay of whole plants. The results of pathogenicity trials revealed that the filamentous parasitic organisms Phytophthora spp. (class Oomycetes) occurring in the soil can be pathogenic for both strawberry and raspberry plants, showing no host specificity.

Acknowledgments The authors would like to thank Magdalena Ptaszek MSc (Department of Vegetables and Ornamental Plant Diseases, Research Institute of Horticulture) and Aleksandra Trzewik MSc (Independent Laboratory of Microscopy, Research Institute of Horticulture) for precious suggestions and remarks concerning Phytophthora spp. cultivation and A. Trzewik MSc for providing $P$. citrophthora strain RH04/CTPH.

\section{Compliance with ethical standards}

Conflict of interest The authors confirm that they have no conflict of interest.

Open Access This article is distributed under the terms of the Creative Commons Attribution 4.0 International License (http://crea tivecommons.org/licenses/by/4.0/), which permits unrestricted use, distribution, and reproduction in any medium, provided you give appropriate credit to the original author(s) and the source, provide a link to the Creative Commons license, and indicate if changes were made.

\section{References}

1. Aljanabi SM, Martinez I (1997) Universal and rapid salt extraction of high-quality genomic DNA for PCR-based techniques. Nucleic Acids Res 25(22):4692-4693

2. Bertier L, Leus L, D'hondt L, de Cock AWAM, Höfte M (2013) Host adaptation and speciation through hybridization and polyploidy in Phytophthora. PLoS ONE 8(12):e85385. doi:10.1371/ journal.pone.0085385

3. Bielenin A (2002) Grzyby rodzaju Phytophthora w uprawach sadowniczych: występowanie, szkodliwość, I zwalczanie. Zeszyty Naukowe Inst. Sad. i Kwiaciarstwa. Monografie i rozprawy 
4. Bielenin A, Meszka B (2009) Choroby krzewów owocowych. Plantpress Sp.z.o.o, Kraków, 129 s

5. Boersma JG, Cooke DEL, Sivasithamparam K (2000) A survey of wildflower farms in the south-west of Western Australia for Phytophthora spp. associated with root rots. Aust J Exp Agric 40:1011-1019

6. Bonants P, Hagenaar de Weerdt M, van Gent-Pelzer M, Lacourt I, Dooke DEL, Duncan M (1997) Detection and identification of Phytophthora fragariae Hickman by the polymerase chain reaction. Eur J Plant Pathol 103:345-355

7. Brasier CM, Cooke DEL, Duncan JM, Hansen EM (2003) Multiple new phenotypic taxa from trees and riparian ecosystems in Phytophthora ganapodyides-P. megasperma ITS Clade 6, which tend to be high-temperature tolerant and either inbreeding or sterile. Mycol Res 107:277-290

8. Cahill DM, Hardham AR (1994) Exploitation of zoospore taxis in the development of a novel dipstick immunoassay for the specific detection of Phytophthora cinnamomi. Phytopathology 84:193-200

9. Cooke DEI, Kennedy DM, Guy DC, Russell J, Unkles SE, Duncan JM (1996) Relatedness of Group I species of Phytophthora as assessed by randomly amplified polymorphic DNA (RAPDs) and sequences of ribosomal DNA. Mycol Res 100:297-303

10. Ellis MA, Madden LV (1998) Leather rot. In: Maas JL (ed) Compendium of strawberry diseases, 2nd edn. American Phytopathological Society Press, St. Paul, pp 33-35

11. Ersek T, Schoelz JE, English JT (1994) PCR amplification of species-specific DNA sequences can distinguish among Phytophthora species. Appl Environ Microb 60(7):2616-2621

12. Erwin DC, Ribeiro OK (1996) Phytophthora: diseases worldwide. American Phytopathological Society Press, St. Paul

13. Fujita DB (1990) Crown, collar, and root rot. In: Jones AL, Aldwinkle HS (eds) Compendium of apple and pear diseases. American Phytopathological Society Press, St. Paul

14. Gerlach WWP, Hoitink HAJ, Schmitthenner AF (1976) Phytophthora citrophthora on Pieris japonica: infection, sporulation, dissemination. Phytopathology 66:302-308

15. Goodwin SB (1997) Population genetics of Phytophthora. Phytopathology $87: 462-473$

16. Grove GG, Madden LV, Ellis MA (1985) Splash dispersal of Phytophthora cactorum from infected strawberry fruit. Phytopathology 75(5):611-615
17. Hantula J, Lilja A, Parikka P (1997) Genetic variation and host specificity of Phytophthora cactorum isolated from Europe. Mycol Res 101:565-572

18. Jung T, Burgess TI (2009) Re-evaluation of Phytophthora citricola isolates from multiple woody hosts in Europe and North America reveals a new species, Phytophthora plurivola sp. nov. Persoonia 22:95-110

19. Jung T, Stukely MJC, St. Hardy GE, White D, Paap T, Burgess TI (2011) Multiple new Phytophthora species from ITS Clade 6 associated with natural ecosystems in Australia: evolutionary and ecological implications. Persoonia 26:13-39

20. Maas JL (1998) Compendium of strawberry diseases. 2nd edn. APS Press, St. Paul, p 98

21. Schubert R, Bahnweg G, Nechwatal J, Jung T, Cooke DEL, Duncan JM, Müller-Starck G, Langebartels C, Sandermann H Jr, Oßwald WF (1999) Detection and quantification of Phytophthora species which are associated with root rot diseases in European deciduous forests by species-specific polymerase chain reaction. Eur J For Pathol 29:169-188

22. Shea SR, Gillen KJ, Leppard WI (1980) Seasonal variation in population levels of Phytophthora cinnamomi Rands in soil in diseased, freely-drained Eucalyptus marginata $\mathrm{Sm}$. sites in the northern Jarrah Forest of south-western Australia. Prot Ecol 2:135-156

23. Themann K, Werres S, Luttmann R, Diener HA (2002) Observations of Phytophthora spp. in water recirculation systems in commercial hardy ornamental nursery stock. Eur J Plant Pathol 108:337-343

24. Upstone ME (1978) Phytophthora syringae fruit of apples. Plant Pathol 27:24-30

25. Waterhouse GM (1957) Phytophthora citricola Sawada (syn. P. cactorum var. applanata Chester). Trans $\mathrm{Br}$ Mycol Soc 40:349-357

26. White TJ, Bruns T, Lee S, Taylor J (1990) Amplification and direct sequencing of fungal ribosomal RNA genes for phylogenetics. In: Innis MA, Gelfand DH, Sninsky JJ, White TJ (eds) PCR protocols: a guide to methods and applications. Academic Press, San Diego, pp 315-322 